\title{
Anti-mycobacterium tuberculosis activity of polyherbal medicines used for the treatment of tuberculosis in Eastern Cape, South Africa.
}

\author{
Elizabeth B Famewo ${ }^{1}$, Anna M Clarke ${ }^{1}$, Ian Wiid ${ }^{2}$, Andile Ngwane ${ }^{2}$, \\ Paul van Helden ${ }^{2}$, Anthony J Afolayan ${ }^{1}$
}

1. Faculty of Science and Agriculture, University of Fort Hare, Alice 5700, South Africa

2. DST-NRF Centre of Excellence for Biomedical Tuberculosis Research, SAMRC Centre for Tuberculosis Research, Division of Molecular Biology and Human Genetics, Faculty of Medicine and Health Sciences, Stellenbosch University, PO Box 241, Cape Town 8000, South Africa.

\author{
Author details \\ efamewo@ufh.ac.za \\ aclarke@ufh.ac.za \\ iw@sun.ac.za \\ ngwane@sun.ac.za \\ pvh@sun.ac.za \\ Afolayanaafolayan@ufh.ac.za
}

\begin{abstract}
Background: The emergence of drug-resistant strains of Mycobacterium tuberculosis has become a global public health problem. Polyherbal medicines offer great hope for developing alternative drugs for the treatment of tuberculosis.

Objective: To evaluate the anti-tubercular activity of polyherbal medicines used for the treatment of tuberculosis.

Methods: The remedies were screened against Mycobacterium tuberculosis H37Rv using Middlebrook 7H9 media and MGIT BACTEC 960 system. They were liquid preparations from King Williams Town site A (KWTa), King Williams Town site B (KWTb), King Williams Town site C (KWTc), Hogsback first site (HBfs), Hogsback second site (HBss), Hogsback third site (HBts), East London (EL), Alice (AL) and Fort Beaufort (FB).

Results: The susceptibility testing revealed that all the remedies contain anti-tubercular activity with KWTa, KWTb, KWTc, HBfs, HBts, AL and FB exhibiting more activity at a concentration below $25 \mu \mathrm{l} / \mathrm{ml}$. Furthermore, MIC values exhibited inhibitory activity with the most active remedies from KWTa, HBfs and HBts at $1.562 \mu \mathrm{g} / \mathrm{ml}$. However, isoniazid showed more inhibitory activity against $M$. tuberculosis at $0.05 \mu \mathrm{g} / \mathrm{ml}$ when compare to the polyherbal remedies.

Conclusion: This study has indicated that these remedies could be potential sources of new anti-mycobacterial agents against M. tuberculosis. However, the activity of these preparations and their active principles still require in vivo study in order to assess their future as new anti-tuberculosis agents.
\end{abstract}

Keywords: Mycobacterium tuberculosis; in vitro activity, polyherbal medicines, South Africa.

DOI: https://dx.doi.org/10.4314/ahs.v17i3.21

Cite as: Famewo EB, Clarke AM, Wiid I, Ngwane A, Helden Pv, Afolayan AJ. Anti-mycobacterium tuberculosis activity of polyherbal medicines used for the treatment of tuberculosis in Eastern Cape, South Africa. Afri Health Sci. 2017;17(3): 780-789. bttps://dx.doi.org/10.4314/abs. $v 17 i 3.21$

\section{Corresponding author: \\ Anthony J Afolayan \\ Faculty of Science and Agriculture, University of Fort Hare \\ Alice 5700, South Africa \\ Tel.:+27 822022167 \\ E-mail: aafolayan@ufh.ac.za}

\section{Introduction}

Mycobacterium tuberculosis, the leading causative agent of tuberculosis (TB) is responsible for the morbidity and mortality of a large population worldwide ${ }^{1}$. TB has a long co-evolutionary history with humans. It does not exhibit any symptom of disease except when impairment of immunity arises due to malnutrition, diabetes, malignancy and $\mathrm{AIDS}^{2}$; however, about $10 \%$ of healthy individuals 
may develop active TB in their life time due to genetic factors. The ability of TB to resist drugs and the influence of HIV epidemic has made the disease remain a devastating global public health problem ${ }^{3}$. According to $\mathrm{WHO}^{4}$, one-third of the world's population have been infected with Mycobacterium tuberculosis (MTB). In 2014, an estimated number of 9.6 million new TB infections were reported, of which 5.4 million were men; 3.2 million were women and 1.0 million children ${ }^{3}$. This disease is responsible for approximately two million deaths annually ${ }^{5}$.

Some of the main obstacles to the global control of the disease are the HIV epidemic that has dramatically increased the risk of developing active TB, increasing emergence of multidrug resistant-TB (MDR-TB: resistance to isoniazid and rifampin) and refractory nature of latent TB treatment to conventional anti-TB drugs ${ }^{6,7,8,9}$. The situation is further exacerbated by the increasing development of extensively drug-resistant (resistant to MDR-TB, all fluoroquinolones and at least one of the second-line anti-TB injectable drugs including amikacin, kanamycin and/or capreomycin) ${ }^{10,11}$. According to the modes of action of these drugs, they can be grouped as cell wall inhibitors (isoniazid, ethambutol, ethionamide, cycloserine), nucleic acid synthesis inhibitors (rifampicin and quinolones), protein synthesis inhibitors (streptomycin, kanamycin) and inhibitors of membrane energy metabolism (pyrazinamide) ${ }^{12,13,14}$. For instance, Isoniazid (INH )is the most widely used treatment for TB and its latent infections ${ }^{15}$. This drug enters the cell as a pro-drug, which is activated by MTB catalase-peroxidase enzyme (KatG). The enzyme activates INH and facilitates its interaction with various toxic reactive species (oxides, hydroxyl radicals and organic moieties) in the bacterial cell ${ }^{16}$, thereby, weakening the components of the cell wall and finally, the death of the bacteria ${ }^{17}$. INH targets inhA enzyme (enoylacyl carrier protein reductase), which is involved in the elongation of fatty acids in mycolic acid synthesis ${ }^{18}$. The replacement of an amino acid in the NADH binding site of inhA results into INH resistance, preventing the inhibition of mycolic acid biosynthesis ${ }^{19}$. INH-resistant strains often lose catalase and peroxidase activities due to KatG Ser315Thr mutation ${ }^{20}$. Resistance to INH can also occur through mutations in the promoter region of inhA, leading to over expression of inhA, or by mutations at the inhA active site, thereby lowering inhA affinity for $\mathrm{INH}^{21}$.
Rifampicin (RIF) have been used as first-line drug in combination with other therapies for the treatment of TB infections. RIF is believed to inhibit bacterial DNA-dependent RNA polymerase? ${ }^{9}$ This drug interferes with RNA synthesis by binding to the $\beta$ subunit of mycobacterial RNA polymerase, which is encoded by $\mathrm{rpoB}$, thereby killing the organism. Resistance to RIF arises due to missense mutations in the gene. Mtb resistance to RIF occurs at a frequency of $10-7$ to $10-8$ as a result of mutations in $\mathrm{rpoB}^{22}$. About $96 \%$ of all mutations are found in the 81-bp core region of the gene between codons 507 and 533, with the most common changes occurring in codons Ser531Leu,His526Tyr and Asp516Val ${ }^{23}$.

Pyrazinamide (PZA) is another vital first-line drug used for the treatment of TB. It plays an important role in reducing the duration of TB treatment ${ }^{24}$. PZA is a pro-drug that requires conversion to its active form, pyrazinoic acid (POA) by the mycobacterial enzyme pyrazinamidase/nicotinamidase. The efflux system of the mycobacterial cell enables massive accumulation of POA in the bacterial cytoplasm, leading to disruption of the bacterial membrane potential ${ }^{25,26}$. The exact mechanism of PZA resistance remains unknown'. However, PZA resistance has been associated with defective pyrazinamidase/nicotinamidase activity which results from mutations that might occur at different regions (3-17, 61-85 and 132-142) of pyrazinamidase/ nicotinamidase ${ }^{27}$.

Ethambutol (EMB) is a first-line drug used in combination with INH, RIF and PZA preventing the emergence of drug resistance mycobacterium. This drug interferes with the cell wall of MTB through a synthetic mechanism thereby inhibiting arabinosyl-transferase (embB), an enzyme involved in cell wall biosynthesis 28 . The enzyme has been proposed as the target of EMB in Mtb11. Mutation is the cause of EMB resistance and it occurs at a rate of approximately 1 in 107 organisms. It increases the production of arabinosyl-transferase, which overwhelms the inhibitory effects of EMB. Studies have revealed five mutations in codon 306 accounting $70-90 \%$ of all EMB resistant strains ${ }^{29}$. The resistance of $\mathrm{Mtb}$ to $\mathrm{TB}$-drugs is mostly due to mutation which is a cause for concern. Therefore, it is important to search for new anti-tuberculosis agents, preferably those that can be readily and simply produced from medicinal plants. 
It has been estimated that about $80 \%$ of South African population is infected with tuberculosis, with $88 \%$ highest prevalence of latent TB among the age group of 3039 years old living in the rural settlements ${ }^{30}$. However, the strains of drug resistant tuberculosis have been on increase yearly in the country ${ }^{31}$.

Polyherbal remedies have been used extensively for the treatment of various diseases for many centuries. They are mixtures of various herbs which contain multiple active constituents and act synergistically against infections $^{32}$. Natural products and/or their semi-synthetic derivatives are important sources of new chemical compounds that might play an important role in the chemotherapy of tuberculosis ${ }^{33}$. Several studies on the use of polyherbal medicines have revealed that these therapies possess pharmacological functions. For instance, Rajanyamalakadi, a polyherbal preparation which contains three herbal ingredients has been proven to show significant anti-diabetic, hypolipidemic and anti-oxidant properties ${ }^{34}$. Also, Polyherbal health tonic tea used for the treatment of an array of diseases affecting humans and Sanjivani Vati used for the treatment of cough and cold have been shown to possess significant pharmacological activities $^{35,36}$. Other Polyherbal remedies such as Livina, Rhumapar tablet, Diakyur and Sugar Remedy have been proven to contain pharmacological activities ${ }^{37,38,39,40}$.

Many researchers have reported on the inhibitory properties of medicinal plants against Mycobacterium tuberculosis both in South Africa and in other countries ${ }^{33,41,42}$ but there is a dearth of information on the inhibitory properties of polyherbal medicines against this organism. The aim of the present study therefore was to evaluate polyherbal remedies used for the treatment of TB for anti-Mycobacterium tuberculosis activities.

\section{Materials and methods \\ Collection of polyherbal medicines}

A total of nine polyherbal medicines evaluated in this study were purchased from herbal sellers in five communities namely; Alice, Fort Beaufort, Hogsback, King Williams Town and East London in Amathole District Municipality of the Eastern Cape Province, South Africa (Figure 1). Each remedy was labelled and coded according to the place of collection; viz: King Williams Town site A (KWTa), King Williams Town site B (KW'Tb), King Williams Town site C (KWTc), Hogsback first site (HBfs), Hogsback second site (HBss), Hogsback third site (HBts), East London (EL), Alice (AL) and Fort Beaufort (FB). The small number of remedies obtained in this study was due to the fact that only a few traditional healers treat and sell remedies for TB. They claim to have acquired the knowledge from their ancestors; and this knowledge is been transferred from one generation to another. The herbal ingredients present in each of the remedies are shown in Table 1 . The remedies were already prepared with water by the herbal sellers into clean 2-litre containers. They were then transported to Medicinal Plants and Economic Development Research Centre, University of Fort Hare for analysis. 


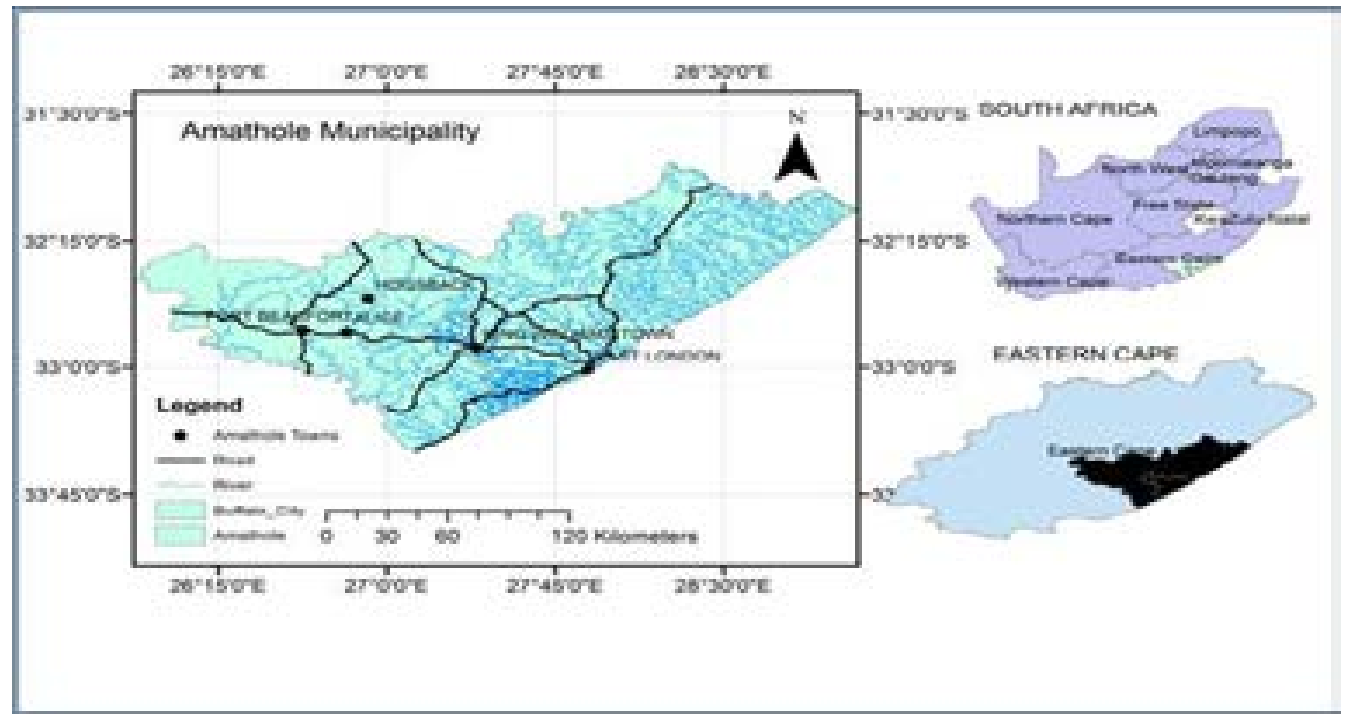

Figure 1: Map of Amathole District Municipality ${ }^{43}$

Table 1: Herbal ingredients present in each of the polyherbal medicines used for the treatment of tuberculosis in Amathole district municipality,

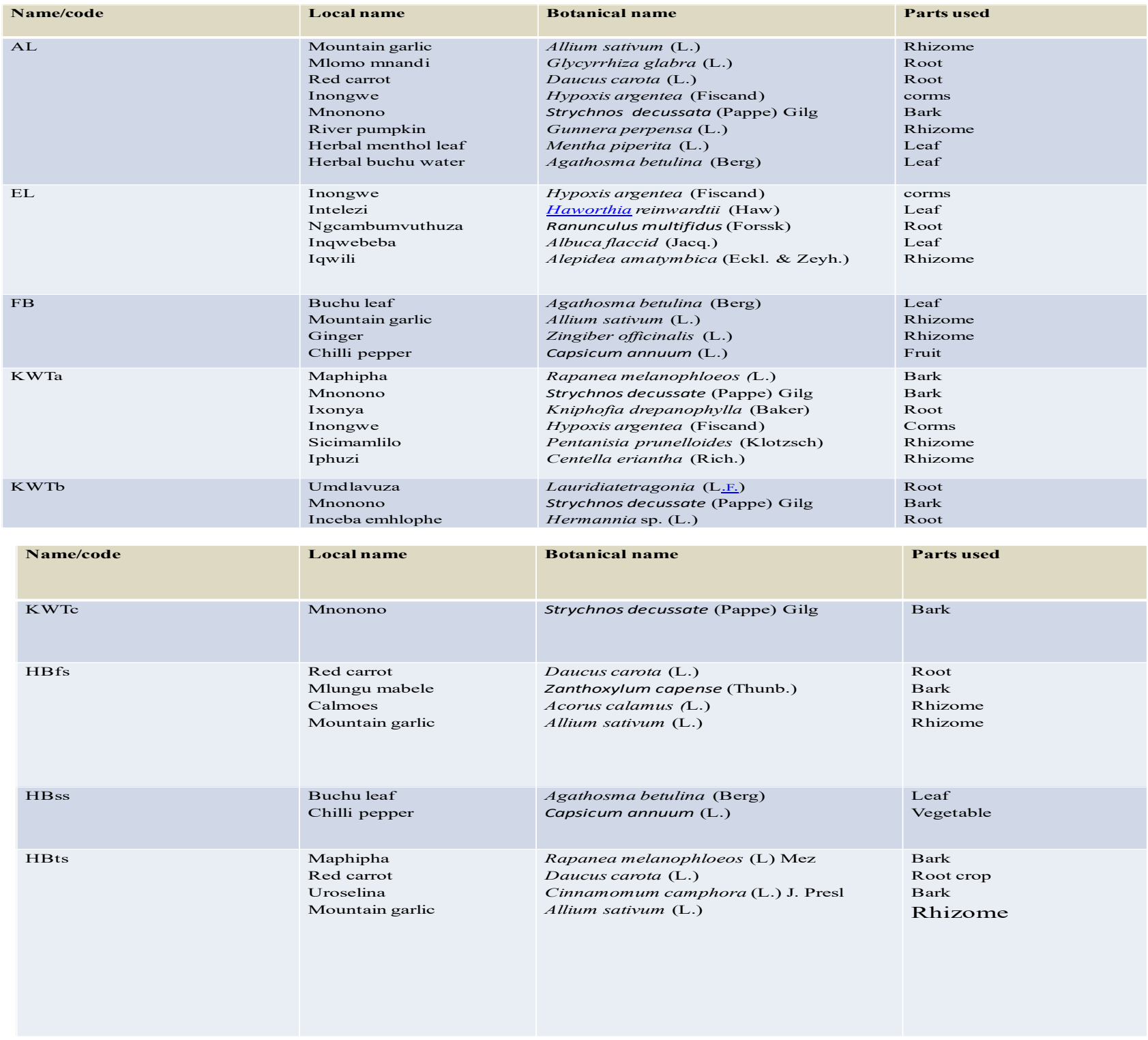




\section{Sample preparation}

The already prepared water remedies were put in 2-liter containers. Each remedy was filtered with a Buchner funnel and Whatman No. 1 filter paper. The filtrate obtained was frozen at $-40^{\circ} \mathrm{C}$ and freeze dried for $48 \mathrm{~h}$ using a freeze dryer (Vir-Tis benchtop K, Vir-Tis Co., Gardiner, NY). The resulting sample was dissolved in 100\% dimethylsulfoxide (DMSO) to a concentration of $50 \mathrm{mg} /$ $\mathrm{ml}$ to make a stock solution ${ }^{45}$.

\section{Microbial strain and medium used for the assays}

Reference MTB strain H37Rv (ATCC 25618) was used for the anti-Mycobacterium tuberculosis assay. It was obtained from American Type, MD, USA Culture Collection. Bacterial culture with DMSO $(1.2 \%)$, isoniazid $(\mathrm{INH})$ at MIC99 $(0.05 \mu \mathrm{g} / \mathrm{ml})$ and bacterial culture only were used as controls ${ }^{46}$.

\section{Bacterial culture and drug preparation}

Suspensions of Mycobacterium tuberculosis H37Rv were grown using mycobacterial growth indicator tubes (MGIT). The inocula were prepared from Lowenstein-Jensen slants. To prepare an inoculum that was less than 15 days old from a culture grown on Lowenstein-Jensen medium, a suspension was prepared in saline and adjusted to a 1.0 $\mathrm{McF}$ arland standard. The suspension was vortexed for several minutes and was allowed to stand for $20 \mathrm{~min}$ for the initial settling of larger particles. The supernatant was transferred to an empty sterile tube and was allowed to stand for an additional $15 \mathrm{~min}$. After being transferred to a new sterile tube, it was then adjusted to a $0.5 \mathrm{McF}$ arland turbidity standard by visual comparison. A 1:5 dilution of the bacterial suspension was prepared, and $0.5 \mathrm{ml}$ was inoculated into MGIT 7H12® (MGIT 960 system, Becton Dickinson, Sparks, USA) tubes containing test and control compounds ${ }^{46}$.

The growth of the organism was monitored through fluorescent changes due to oxygen consumption in the medium during active growth. Aliquots $(100 \mu \mathrm{l})$ of each herbal medicine was added to the MGIT tubes containing bacteria in Middlebrook $7 \mathrm{H} 12{ }^{\circledR}$ media, with the final DMSO concentration not exceeding 1.2\%. The tubes were incubated at $37^{\circ} \mathrm{C}$ in MGIT system, and growth units $(\mathrm{GU})$ were monitored for six days. All the remedies were tested at concentrations of 50 and $25 \mathrm{ug} / \mathrm{ml}^{46}$.

For MIC99 evaluations, a 1\% bacterial control culture was prepared in a drug-free MGIT tube and the $\mathrm{MIC}_{99}$ of the compound determined relative to the growth units of the control (GU-400). The MIC was determined as the lowest drug concentration that equals or lower than $\mathrm{GU}$ of the $1 \%$ bacterial culture. Controls that were also included are bacterial culture with DMSO $(1.2 \%)$, isoniazid (INH) and bacterial culture only. All the herbal preparations were tested at two-fold decreasing concentration ${ }^{46}$.

\section{Results}

In the present study, the susceptibility and minimum inhibitory concentration (MIC) of nine polyherbal medicines were determined against $M$. tuberculosis $\mathrm{H} 37 \mathrm{Rv}$, in vitro. The susceptibility testing revealed that all the remedies have anti-tubercular activity against $M$. tuberculosis $\mathrm{H} 37 \mathrm{Rv}$ at concentrations below $50 \mathrm{ug} / \mathrm{ml}$. Seven of these polyherbal preparations, namely; KW'Ta, KW'Tb, KW'Tc, HBfs, HBts, AL and FB showed activity at concentrations below $25 \mathrm{ug} / \mathrm{ml}$, with the remaining remedies showing activity at concentrations between 25 and $50 \mathrm{ug} / \mathrm{ml}$ (Table 2).

All the remedies exhibited inhibitory activity against $M$. tuberculosis $\mathrm{H} 37 \mathrm{Rv}$ with $\mathrm{KWTa}$, HBfs and $\mathrm{HBts}$ as the most active remedies at $1.562 \mu \mathrm{g} / \mathrm{ml}$, followed by AL remedy which showed growth inhibition at $3.125 \mu \mathrm{g} / \mathrm{ml}$. The remaining preparations from KWTb, KWTc, HBss, $\mathrm{EL}$ and FB showed growth inhibition against $M$. tuberculosis at $25 \mu \mathrm{g} / \mathrm{ml}$. However, isoniazid showed more inhibitory activity against $M$. tuberculosis $\mathrm{H} 37 \mathrm{Rv}$ at $0.05 \mu \mathrm{g} / \mathrm{ml}$ when compared to the polyherbal remedies (Table 2). 
Table 2. Susceptibility testing and minimum inhibition concentration (MIC 99 ) of nine polyherbal remedies against $M$. tuberculosis H37Rv using MGIT BACTEC 960 system

\begin{tabular}{|c|c|c|c|}
\hline $\begin{array}{l}\text { Polyherbal } \\
\text { remedies }\end{array}$ & $\begin{array}{l}\text { Susceptibility } \\
\text { activity }(\mu \mathrm{g} / \mathrm{ml})\end{array}$ & $\begin{array}{l}\begin{array}{l}\text { MIC }_{99} \text { of } \\
(\mu \mathrm{g} / \mathrm{ml})\end{array} \\
\end{array}$ & remedies \\
\hline KWTa & $<25$ & $<1.562$ & \\
\hline KWTb & $<25$ & 25 & \\
\hline KWTc & $<25$ & 25 & \\
\hline HBfs & $<25$ & $<1.562$ & \\
\hline HBss & $>25$ & 25 & \\
\hline HBts & $<25$ & $<1.562$ & \\
\hline AL & $<25$ & 3.125 & \\
\hline EL & $>25$ & 25 & \\
\hline FB & $<25$ & 25 & \\
\hline Isoniazid (INH) & - & 0.05 & \\
\hline
\end{tabular}

\section{Discussion}

Tuberculosis has been a major health problem for developing countries including South Africa. The increasing resistance of the disease to first and second line drugs has demanded the need for a new search for anti-mycobacterial agents that could be effective, efficient, non-toxic and cost effective ${ }^{47}$.

The herbal preparations from KWTa, HBfs, HBts and AL showed a greater anti-mycobacterial activity, resulting in lower susceptibility patterns and MIC values observed. From observation, the aforementioned remedies contain a mixture of two or more of the following herbs: Allium sativum, Strychnos decussata, Daucus carota, Hypoxis argentea, Rapanea melanophloeo together with other herbs. Species of these plants have been investigated and shown to contain anthraquinones, glycosides, saponins, tannins, terpenoids, aloin, saponins, steroids and flavonoids ${ }^{48,49,50}$. Other compounds include alkaloids, terpenes, resin, monoterpenoids, sesquiterpenoids and phenols which show activity against Mycobacterium tuberculosis ${ }^{51,15,52}$. Allium sativum is a plant that has been reported as an established remedy for the treatment of tuberculosis ${ }^{53}$. It possesses variety of biological properties such as anti-cancer, anti-microbial, antioxidant, immunomodulatory, anti-inflammatory, hypoglycaemic and anti-cardiovascular properties ${ }^{54}$. Several studies conducted on the in vitro activity of Allium sativum against Mycobacterium tuberculosis revealed that this plant possesses anti-tubercular properties ${ }^{41,42,53,53}$. The presence of sulphur compounds such as allicin, ajoene, allylmethyltrisulfide, diallyltrisulfide, diallyldisulphide has been associated with the anti-tubercular activity of this Allium sativum ${ }^{55}$.
Information on the use of Strychnos decussate as an anti-tubercular agent has not been reported. This study is the first to report the use of this plant as a remedy for the treatment of TB. However, it has been reported to possess anti-fungal activity ${ }^{56}$. Daucus carota is a root vegetable. There are only a few reports on the anti-tubercular activity of this plant ${ }^{57,58}$. However, it has been reported to be used as an anti-bacterial ${ }^{59}$, anti-fertility ${ }^{60}$, anti-oxidant ${ }^{61}$, ophthalmic and stimulant ${ }^{62}$, anti-septic, diuretic, hepatoprotective, anti-inflammatory ${ }^{63,64}$, anti-helmintic, carminative ${ }^{65}$, deobstruent, diuretic and galactogogue. According to the reports, phenolics, polyacetylenes, carotenoids, ascorbic acid and tocopherol are the most abundant phytonutrients present in this plant ${ }^{66}$. Hypoxis argentea has also been reported to be used as a remedy for the treatment of $\mathrm{TB}^{58}$. Species of the genus Hypoxis have been used as anti-bacterial, anti-fungal, anti-viral, anti-oxidant, anti-inflammatory, anti-diabetic, cardiovascular, anti-convulsant and anti-cancer ${ }^{67,68,69,70,71}$. The presence of several compounds, especially glucosides, sterols and sterolins could be responsible for the different activities found in $\mathrm{Hy}$ poxis ${ }^{72}$. Rapanea melanophloeo has been screened for activity and found active against drug-resistant and drug-sensitive strains of Mycobacterium tuberculosis ${ }^{73,74}$. This plant has been reported to contain bioactive compounds such as benzoquinones, saponins and tannins which could probably contribute to its activity ${ }^{73}$.

The high activity of these polyherbal remedies against $M$. tuberculosis could be attributed to the presence of multiple active constituents which may act in synergy and produce greater anti-mycobacterial activity. This is an indication that many natural products are potential source of antimycobacterial agents ${ }^{42}$. 


\section{Conclusion}

This study has revealed that polyherbal remedies have the potential to cure tuberculosis. This is the first research work on the anti-tuberculosis activity of polyherbal medicines used for the treatment of tuberculosis in South Africa. The remedies might be potential sources of new anti-mycobacterial agents as they all showed activity against M. tuberculosis. However, the activity of these remedies and their active principles still require in vivo study in order to validate their potential as anti-tuberculosis agents.

\section{Acknowledgement}

The work was supported by the National Research Foundation, South Africa.

\section{Conflict of interest}

The authors declare no conflict of interest.

\section{References}

1. Baldwin PR, Reeves AZ, Powell KR, Napier RJ, Swimm AI, Sun A, Giesler K, Bommarius B, Shinnick TM, Snyder JP, Liotta DC. Monocarbonyl analogs of curcumin inhibit growth of antibiotic sensitive and resistant strains of Mycobacterium tuberculosis. European Journal of Medicinal Chemistry 2015; 6 (92): 693 - 9, doi:10.1016/j.ejmech.2015.01.020

2. Antony M, James J, Misra CS, Sagadevan LDM, Veettil AT, Thankamani V. Anti-mycobacterial activity of the plant extracts of Alstonia scholaris. International Journal of Current Pharmacentical Research 2012; 4 (1): 40 - 42.

3. Tang J, Yam WC, Chen Z. Mycobacterium tuberculosis infection and vaccine development. Tuberculosis 2016; 98: 30 - 41, doi:10.1016/j.tube.2016.02.005

4. WHO. Global tuberculosis report. World Health Organization; Geneva 2015.

5. Ibekwe NN, Ameh SJ. Plant natural products research in tuberculosis drug discovery and development: A situation report with focus on Nigerian biodiversity. African Journal of Biotechnology 2015; 13 (23): 2307 - 2320, doi:10.5897/AJB2013.13491.

6. Corbett EL, Watt CJ, Walker N, Maher D, Williams BG, Raviglione MC, Dye C. The growing burden of tuberculosis: global trends and interactions with the HIV epidemic. Archives of Internal Medicine 2003; 163: 1009 - 1021, doi:10.1001/archinte.163.9.1009.

7. Gomez JE, McKinney JD. Mycobacterium tuberculosis persistence, latency, and drug tolerance. Tuberculosis (Ed- inb) 2004; 84: 29 - 44, doi:10.1016/j.tube.2003.08.003. PubMed

8. Smith CV, Huang CC, Miczak A, Russell DG, Sacchettini JC, Honer zu Bentrup K Biochemical and structural studies of malate synthase from Mycobacterium tuberculosis. Journal of Biological Chemistry 2003; 278: 1735 - 1743, doi: 10.1074/jbc.M209248200

9. Shehzad A, Rehman G, Ul-Islam M, Khattak WA, Lee YS. Challenges in the development of drugs for the treatment of tuberculosis. Brazilian Journal of Infectious Diseases 2013; 17 (1): 74 - 81, http://dx.doi.org/10.1016/j. bjid.2012.10.009.

10. Centers for Disease Control and Prevention (CDC). Emergence of Mycobacterium tuberculosis with extensive resistance to second-line drugs--worldwide, 2000-2004. MMWR. Morbidity and mortality weekly report 2006; 55 (11): $301-305$

11. Zhang Y, Yew WW. Mechanisms of drug resistance in Mycobacterium tuberculosis [State of the art series. Drug-resistant tuberculosis. Edited by CY. Chiang. Number 1 in the series]. The International Journal of Tuberculosis and Lung Disease. 2009; 13 (11): 1320 - 1330, PubMed.

12. Al-Deeb AO, Alafeefy AM. Synthesis of some new $3 \mathrm{H}$-quinazolin-4-one derivatives as potential anti-tubercular agents. World Apply Science Journal 2008; 5 (1): 94 - 99. 13. Trivedi AR, Siddiqui AB, Shah VH. Design, synthesis, characterization and antitubercular activity of some 2-heterocycle-substituted phenothiazines. Arkivoc. 2008; 1 (2): 210- 217. PubMed

14. Islam M, Siddiqui AA, Rajesh R. Synthesis, antitubercular, antifungal and anti-bacterial activities of 6-substituted phenyl-2-(3í-substituted phenyl pyridazin-6í-yl)-2,3,4,5-tetrahydropyridazin-3-one. Acta Poloniae Pharmacentica 2008; 65 (3): 353 - 362.

15. Heym B, Saint-Joanis B, Cole ST. The molecular basis of isoniazid resistance in Mycobacterium tuberculosis. Tubercle and Lung Disease 1999; 79: 267 - 271, doi:10.1054/ tuld.1998.0208.

16. Barry CE, Lee RE, Mdluli K, Sampson AE, Schroeder BG, Slayden RA, Yuan Y. Mycolic acids: structure, biosynthesis and physiological functions. Progress in lipid research 1998; 37: 143 - 79, doi:10.1016/S0163-7827(98)00008-3

17. Winder F. Mode of action of the antimycobacterial agents and associated aspects of the molecular biology of mycobacteria. In: Ratledge C, Stanford J, editors. The biology of mycobacteria, vol. 1. New York: Academic Press; 1982. p. $354-438$. 
18. Zhang Y, Telenti A. Genetics of drug resistance in Mycobacterium tuberculosis. In: Hatful GF, Jacobs Jr WR, editors. Molecular genetics of mycobacteria. Washington DC: ASM Press; 2000. p. 235 - 54.

19. Telenti A, Imboden P, Marchesi F. Detection of rifampicin-resistance mutations in Mycobacterium tuberculosis. Lancet 1993; 341: 647-50 PubMed, doi:10.1016/01406736(93)90417-F.

20. Hazbon MH, Brimacombe M, Bobadilla del Valle M, Cavatore M, Guerrero MI, Varma-Basil M. Population genetics study of isoniazid resistance mutations and evolution of multidrug-resistant Mycobacterium tuberculosis. Antimicrobial agents and chemotherapy 2006; 50 (8): 2640 - 2649, doi: 10.1128/AAC.00112-06.

21. Rozwarski DA, Grant GA, Barton DH, Jacobs WR,Jr, Sacchettini JC. Modification of the NADH of the isoniazid target (InhA) from Mycobacterium tuberculosis. Science 1998; 279 (5347): 98-102, doi: 10.1126/science.279.5347.98.

22. Dye C, Williams BG. The population dynamics and control of tuberculosis. Science 2010; 328: 856 - 861 PubMed, doi:10.1126/science.1185449.

23. Zhang Y, Wade MM, Scorpio A, Zhang H, Sun Z. Mode of action of pyrazinamide: disruption of Mycobacterium tuberculosis membrane transport and energetics by pyrazinoic acid. Journal of Antimicrobial Chemotherapy 2003; 52: 790 - 795, doi: 10.1093/jac/dkg446.

24. Salfinger M, Crowle AJ, Reller LB. Pyrazinamide and pyrazinoic acid activity against tubercle bacilli in cultured human macrophages and in the BACTEC system. Journal of Infectious Diseases 1990; 162: 201 - 207, doi: 10.1093/ infdis/162.1.201.

25. Zhang Y, Scorpio A, Nikaido H, Sun Z. Role of acid $\mathrm{pH}$ and deficient efflux of pyrazinoic acid in unique susceptibility of Mycobacterium tuberculosis to pyrazinamide. Journal of Bacteriology 1999; 181: 2044 - 2049.

26. Sheen P, Ferrer P, Gilman RH, López-Llano J, Fuentes P, Valencia E, Zimic MJ. Effect of pyrazinamidase activity on pyrazinamide resistance in Mycobacterium tuberculosis. Tuberculosis 2009; 89: 109 - 113 PubMed, doi:10.1016/j.tube.2009.01.004.

27. Scorpio A, Zhang Y. Mutations in pncA, a gene encoding pyrazinamidase/nicotinamidase, cause resistance to the antituberculous drug pyrazinamide in tubercle bacillus. Nature Medicine 1996; 2 (6): 662 - 667, doi:10.1038/ nm0696-662.

28. Telenti A, Philipp WJ, Sreevatsan S, Bernasconi C,
Stockbauer KE, Wieles B, Musser JM, Jacobs WR. The emb operon, a gene cluster of Mycobacterium tuberculosis involved in resistance to ethambutol. Nature Medicine 1997; 3 (5): 567 - 570, doi:10.1038/nm0597-567.

29. Van Niekerk C, Ginsberg A. Assessment of global capacity to conduct tuberculosis drug development trials: do we have what it takes? The International Journal of Tuberculosis and Lung Disease 2009; 13: 1367 - 1372.

30. TB Statistics South Africa. TB Statistics for South Africa - National \& provincial 2015.

31. Hughes J, Osman M. Diagnosis and management of drug-resistant tuberculosis in South African adults. SAMJ: South African Medical Journal 2014; 104: 0 - 0, http://dx. doi.org/10.7196/SAMJ.9097.

32. Bhope, SG, Nagore DH, Kuber VV, Gupta PK, Patil MJ. Design and development of a stable polyherbal formulation based on the results of compatibility studies. Pharmacognosy Research 2011; 3: 122, doi: 10.4103/09748490.81960.

33. Pavan FR., Leite CQF, Coelho RG, Coutinho ID, Honda NK, Cardoso CAL, Sato DN. Evaluation of anti-Mycobacterium tuberculosis activity of Campomanesia adamantium (Myrtaceae). Química Nova 2009; 32: 1222 -1226 PubMed, http:/ / dx.doi.org/10.1590/S010040422009000500026.

34. Faizal P, Suresh S, Kumar RS, Augusti KT. A study on the hypoglycaemic and hypolipidemic effects of an ayurvedic drug Rajanyamalakadi in diabetic patients. Indian Journal of Clinical Biochemistry 2009; 24 (1): 82 - 87, doi: 10.1007/s12291-009-0014-1.

35. Adeneye AA, Benebo AS. Pharmacological evaluation of a Nigerian polyherbal health tonic tea in rat. African Journal of Biomedical Research 2007; 10 (3).

36. Gairola S, Gupta V, Bansal P, Maithani M, Krishna CM. Pharmacological activities of polyherbal formulation: Sanjivani Vati. International Journal of Ayurvedic Medicine 2011; 11: 2 (1).

37. Joshi CS, Priya ES, Venkataraman S. Acute and subacute toxicity studies on the polyherbal antidiabetic formulation Diakyur in experimental animal models. Journal of Health Science 2007; 53 (2): 245 - 249, http://doi. org/10.1248/jhs.53.245.

38. Gulati K, Ray A, Vijayan VK. Assessment of protective role of polyherbal preparation, Livina, against anti-tubercular drug induced liver dysfunction. 2010, http://imsear.hellis.org/handle/123456789/144975.

39. Patil VP, Rajput AP, Chaudhari PM, Chaudhari SP, Baviskar DT. Pharmacological evaluation of marketed 
polyherbal formulation. Asian Journal of Pharmaceutical and Clinical Research 2013; 6 (4): 80 - 85.

40. Singhal S, Rathore AS, Lohar V, Dave R, Dave J. Pharmacological Evaluation of "Sugar Remedy," A Polyherbal Formulation, on Streptozotocin-Induced Diabetic Mellitus in Rats. Journal of Traditional and Complementary Medicine 2014; 4 (3): 189, doi: 10.4103/2225-4110.127800.

41. Green E, Samie A, Obi CL, Bessong PO, Ndip RN. Inhibitory properties of selected South African medicinal plants against Mycobacterium tuberculosis. Journal of Ethnopharmacology 2010; 130 (1): 151 - 157, doi:10.1016/j. jep.2010.04.033

42. Gupta P, Bhatter P, D'souza D, Tolani M, Daswani P, Tetali P, Birdi T. Evaluating the anti-Mycobacterium tuberculosis activity of Alpinia galanga (L.) Willd. axenically under reducing oxygen conditions and in intracellular assays. BMC Complementary and Alternative Medicine 2014; 14: 1. doi: 10.1186/1472-6882-14-84.

43. Famewo EB, Clarke AM, Afolayan AJ. Identification of bacterial contaminants in polyherbal medicines used for the treatment of tuberculosis in Amatole District of the Eastern Cape Province, South Africa, using rapid 16S rRNA technique. Journal of Health, Population and Nutrition, 2016; 35 (1): 27, doi: 10.1186/s41043-016-0064-y.

44. Famewo EB, Clarke AM, Afolayan AJ. Ethno-medicinal documentation of polyherbal medicines used for the treatment of tuberculosis in Amathole District Municipality of the Eastern Cape Province, South Africa. Pharmacentical Biology 2017; 55 (1): 696 - 700, http://dx.doi.or g/10.1080/13880209.2016.1266670.

45. Koduru S, Grierson DS, Afolayan AJ. Antimicrobial Activity of Solanum aculeastrum. Pharmacentical Biology 2006; 44: 283 - 286, doi:10.1080/13880200600714145.

46. Askun T, Satil F, Tumen G, Yalcin O, Modanlioglu S. Antimycobacterial activity some different Lamiaceae plant extracts containing flavonoids and other phenolic compounds. INTECH Open Access Publisher 2012.

47. Kirimuhuzya C, Waako P, Joloba M, Odyek O. The anti-mycobacterial activity of Lantana camara a plant traditionally used to treat symptoms of tuberculosis in South-western Uganda. African Health Sciences 2009; 9: 40 $-45$.

48. Chah KF, Muko KN, Oboegbulem SI. Antimicrobial activity of methanolic extract of Solanum torvum fruit. Fitoterapia 2000; 71: 187 - 189, doi:10.1016/S0367326X(99)00139-2.

49. Okunade AL, Elvin-Lewis MP, Lewis WH. Natural antimycobacterial metabolites: current status. Phy- tochemistry 2004; 65: 1017-1032, doi:10.1016/j.phytochem.2004.02.013.

50. Ali BH, Blunden G, Tanira MO, Nemmar A. Some phytochemical, pharmacological and toxicological properties of ginger (Zingiber officinale Roscoe): a review of recent research. Food and Chemical Toxicology 2008; 46: 409 -420, doi:10.1016/j.fct.2007.09.085.

51. Arunkumar S, Muthuselvam M. Analysis of phytochemical constituents and antimicrobial activities of Aloe vera L. against clinical pathogens. World Journal of Agricultural Sciences. 2009; 5 (5): 572 - 576.

52. Kose LS, Moteetee A, Van Vuuren S. Medicinal plants used for the treatment of tuberculosis in Lesotho: An ethnobotanical survey. South African Journal of Botany 2015; 98: 183, doi:10.1016/j.sajb.2015.03.059.

53. Hannan A, Ullah MI, Usman M, Hussain S, Absar M, Javed K. Anti-mycobacterial activity of garlic (Allium sativum) against multi-drug resistant and non-multi-drug resistant Mycobacterium tuberculosis. Pakistan Journal of Pharmaceutical Sciences 2011; 24 (1): 81 - 85.

54. Reuter HD, Koch HP, Lawson LD. Therapeutic effects and applications of garlic and its preparations. Garlic: The Science and Therapeutic Application of Allium sativum L. In: Koch HP, Lawson LD, editors. Baltimore, MD, USA: Williams and Wilkins; 1996. pp. 135-512.

55. Viswanathan V, Phadatare AG, Mukne A. Antimycobacterial and antibacterial activity of Allium sativum bulbs. Indian Journal of Pharmacentical Sciences. 2014, doi: 10.4103/0250-474X.135018.

56. Samie A, Tambani T, Harshfield E, Green E, Ramalivhana JN, Bessong PO. Antifungal activities of selected Venda medicinal plants against Candida albicans, Candida krusei and Cryptococcus neoformans isolated from South African AIDS patients. African Journal of Biotechnology 2010; 17: 9 (20).

57. Fitzpatrick FK. Plant substances active against Mycobacterium tuberculosis. Antibiotics and Chemotherapy 1954; 4: 528 - 536, PubMed.

58. Lawal IO, Grierson DS, Afolayan AJ. Phytotherapeutic information on plants used for the treatment of tuberculosis in Eastern Cape Province, South Africa. Evidence-Based Complementary and Alternative Medicine 2014; 22: 2014, http://dx.doi.org/10.1155/2014/735423. 59. Ahmed AA, Bishr MM, El-Shanawany MA, Attia EZ, Ross SA, Paré PW. Rare trisubstituted sesquiterpenes daucanes from the wild Daucus carota. Phytochemistry. 2005; 66 (14): 1680 PubMed - 1684, doi:10.1016/j.phytochem.2005.05.010. 
60. Majumder PK, Dasgupta S, Mukhopadhaya RK, Mazumdar UK, Gupta M. Anti-steroidogenic activity of the petroleum ether extract and fraction 5 (fatty acids) of carrot (Daucus carota L.) seeds in mouse ovary. Journal of Ethnopharmacology 1997; 57 (3): 209 - 212, doi:10.1016/ S0378-8741(97)00056-1.

61. Arabshahi-D S, Devi DV, Urooj A. Evaluation of antioxidant activity of some plant extracts and their heat, pH and storage stability. Food Chemistry 2007; 100 (3): 1100 PubMed - 1115, doi:10.1016/j.foodchem.2005.11.014.

62. Ghisalberti EL. The daucane (carotane) class of sesquiterpenes. Phytochemistry 1994; 37 (3): 597- 623, doi:10.1016/S0031-9422(00)90327-3.

63. Foster S, Duke JA. A field guide to medicinal plants and herbs of eastern and central North America. Houghton Mifflin Harcourt; 2000.

64. Porchezhian E, Ansari SH, Ali M. Analgesic and anti-inflammatory activity of volatile oil from Daucus carota Linn seeds. Indian Journal of Natural Products 2000; 16 (1): $24-26$.

65. Bishayee A, Sarkar A, Chatterjee M. Hepatoprotective activity of carrot (Daucus carota L.) against carbon tetrachloride intoxication in mouse liver. Journal of Ethnopharmacology 1995; 47 (2): 69 - 74, doi:10.1016/03788741(95)01254-B.

66. Sharma KD, Karki S, Thakur NS, Attri S. Chemical composition, functional properties and processing of carrot-a review. Journal of Food Science and Technology 2012; 49 (1): 22 - 32, doi: 10.1007/s13197-011-0310-7.

67. Ker JA. Ventricular tachycardia as an adverse effect of the African Potato (Hypoxis sp.). Cardiovascular journal of South Africa: Official Journal for Southern Africa Cardiac Society [and] South African Society of Cardiac Practitioners 2005; 16 (1): 55, PubMed.
68. Buwa LV, Van Staden J. Antibacterial and antifungal activity of traditional medicinal plants used against venereal diseases in South Africa. Journal of Ethnopharmacology 2006; 103 (1): 139 - 142, DOI:10.1016/j.jep.2005.09.020. 69. Steenkamp V, Gouws MC. Cytotoxicity of six South African medicinal plant extracts used in the treatment of cancer. South African Journal of Botany 2006; 72 (4): 630 633, doi:10.1016/j.sajb.2006.02.004.

70. Steenkamp V, Gouws MC, Gulumian M, Elgorashi EE, Van Staden J. Studies on antibacterial, anti-inflammatory and antioxidant activity of herbal remedies used in the treatment of benign prostatic hyperplasia and prostatitis. Journal of Ethnopharmacology 2006; 103 (1): 71 - 75, doi:10.1016/j.jep.2005.07.007.

71. Drewes SE, Hall AJ, Learmonth RA, Upfold UJ. Isolation of hypoxoside from Hypoxis rooperi and synthesis of (E)-1, 5-bis (3', 4'-dimethoxyphenyl) pent-4-en-1yne. Phytochemistry 1984; 23 (6): 1313-1316, doi:10.1016/ S0031-9422(00)80449-5. PubMed

72. Ncube B, Ndhlala AR, Okem A, Van Staden J. Hypoxis (Hypoxidaceae) in African traditional medicine. Journal of Ethnopharmacology 2013; 50 (3): 818 - 827, doi: 10.1016/j.jep.2013.10.032.

73. Lall N, Meyer JJ. In vitro inhibition of drug-resistant and drug-sensitive strains of Mycobacterium tuberculosis by ethnobotanically selected South African plants. Journal of Ethnopharmacology 1999; 66 (3): 347 - 354, doi:10.1016/ S0378-8741(98)00185-8.

74. Dzoyem JP, Aro AO, McGaw LJ, Eloff JN. Antimycobacterial activity against different pathogens and selectivity index of fourteen medicinal plants used in Southern Africa to treat tuberculosis and respiratory ailments. South African Journal of Botany 2016; 31 (102): 70 - 74, doi:10.1016/j.sajb.2015.08.002. 